\title{
A Polifonia no Discurso Pedagógico do Tutor
}

\author{
Maira Teresinha Lopes Penteado*1
}

1 Investigadora, Centro de Ciências da Educação/Universidade Federal de Santa Catarina. Campus Reitor João David Ferreira Lima, s/n, Trindade. - Florianópolis - SC - Brasil. maira.ead@gmail.com

\section{Resumo}

Este estudo teve como objetivo expandir e incentivar a discussão sobre vozes sociais que compõem o trabalho do tutor. A perspectiva bakhtiniana tem que refletir a função comunicativa e interativa (ética e estética) da polifonia. Tais considerações teóricas contribuem para o desenvolvimento e a qualidade da tutoria.

Palavras-chave: Tutoria; Bakhtin; Polifonia. 


\title{
The Polyphony in Teaching the Tutor Speech
}

\begin{abstract}
This study aimed to expand and encourage discussion about social voices that compound tutor's work. Bakhtinian perspective has to reflect the communicative and interactive function (ethics and aesthetics) of polyphony. Such theoretical considerations contribute to the development and quality of tutoring process.
\end{abstract}

Keywords: Tutoring; Bakhtin; Polyphony. 


\section{Introdução}

Atualmente, diversos autores passaram a se interessar pela contribuição dos estudos de Mikhail Bakhtin sobre a comunicação dialógica na educação a distância. Neste artigo, faremos um recorte sobre o discurso pedagógico do tutor, nesse amplo cenário da modalidade, para dar foco ao âmbito da polifonia na tutoria.

Nessa perspectiva, necessário se faz refletir sobre os processos comunicacionais e suas relações na educação, esclarecendo os elementos que constituem o caráter pedagógico da comunicação, pois os alunos possuem diferentes formas de interpretar a mesma mensagem.

Os tutores são os responsáveis muitas vezes por passar diversas horas de trabalho em contato ou à disposição dos alunos, enfim, o tutor é basicamente um meio de comunicação entre os participantes do curso. Como essa comunicação se dá no ambiente virtual de aprendizagem é o que nos interessa neste texto.

A tutoria é o trabalho de apoio à docência dentro dos ambientes virtuais de ensino e aprendizagem (algumas vezes, presencialmente nos polos de educação a distância). As atividades dos tutores consistem basicamente em:

- $\quad$ estabelecer um diálogo entre os participantes do curso;

- $\quad$ auxiliar o professor na elaboração das atividades, propondo enunciados ou melhorias, quando e se necessário;

- auxiliar na avaliação dos conteúdos e provas/exercícios;

- responder aos questionamentos dos estudantes;

- esclarecer as dúvidas sobre os conteúdos do curso.

Trata-se aqui de uma pesquisa bibliográfica de cunho discursivo com o objetivo de articular a teoria de Bakhtin ao processo de tutoria na educação a distância. Com base em dados bibliográficos sobre a necessidade da formação de tutores para a comunicação dialógica nos ambientes digitais, destacamos as palavras de Moran:

Só vale a pena ser educador dentro de um contexto comunicacional participativo, interativo, vivencial. Só aprendemos profundamente dentro deste contexto. Não vale a pena ensinar dentro de estruturas autoritárias e ensinar de forma autoritária. Pode até ser mais eficiente em curto prazo 
- os alunos aprendem rapidamente determinados conteúdos programáticos - mas não aprendem a ser pessoas, a ser cidadãos. Com ou sem tecnologias avançadas podemos vivenciar processos participativos de compartilhamento de ensinar e aprender (poder distribuído) através da comunicação mais aberta, confiante, de motivação constante, de integração de todas as possibilidades da aula-pesquisa/aula-comunicação, num processo dinâmico e amplo de informação inovadora, reelaborada pessoalmente e em grupo, de integração do objeto de estudo em todas as dimensões pessoais: cognitivas, emotivas, sociais, éticas e utilizando todas as habilidades disponíveis do professor e do aluno. (Moran, 2000, p.9).

Sendo a tutoria uma forma de interação entre equipe do curso e projeto pedagógico, cabe construirmos novas maneiras de se pensar a formação desses profissionais. Este artigo está baseado em um ponto de vista: na análise dialógica do discurso como ponto de partida para essa articulação teórica e metodológica. É necessário que os profissionais de educação a distância saibam quais aspectos de função ética e estética no discurso pedagógico dos tutores servem para qualificar o processo de comunicação nesse contexto.

As relações dialógicas de acordo com a teoria bakhtiniana surgem por meio das enunciações. Vejamos o que Bakthin afirma sobre isso:

Não existe a primeira nem a última palavra, e não há limites para o contexto dialógico (este se estende ao passado sem limites e ao futuro sem limites). Nem os sentidos do passado, isto é, nascidos no diálogo dos séculos passados, podem jamais ser estáveis (concluídos, acabados de uma vez por todas): eles sempre irão mudar (renovando-se) no processo de desenvolvimento subsequente, fruto do diálogo. Em qualquer momento do desenvolvimento do diálogo existem massas imensas e ilimitadas de sentidos esquecidos, mas em determinados momentos do sucessivo desenvolvimento do diálogo, em seu curso, tais sentidos serão relembrados e reviverão em forma renovada (em novo contexto). Não existe nada absolutamente morto: cada sentido terá sua festa de renovação. Questão do grande tempo. (Bakhtin, 2006, p.410).

A tutoria, se pensada como processo polifônico (conjunto de vozes sociais), dentro de um cenário que abrange diálogos, conceitos e enunciados que podem ser renovados, acabará dando um novo verniz ao processo didático favorecendo a produção de sentidos. A atividade de produção e compreensão dos enunciados nas ciências humanas pode ser entendida como os "mediadores dialógicos" da construção do conhecimento. É nesse sentido que o papel do tutor torna-se cada vez mais essencial no que toca a transmitir por meio de seu discurso uma postura ética e ainda evidenciando que seu discurso possui um aspecto e função estética dentro dos ambientes virtuais de ensino e aprendizagem. 
Conforme Bakhtin (2006), todo enunciado concreto ou pleno sugere e aponta uma atitude responsiva. Seu caráter dialógico, aspecto que determina o dialogismo no ato enunciativo, é conferido assim à atitude de resposta do auditório social em questão:

Como a palavra, a oração é uma unidade significativa da língua. Por isso, cada oração isolada, por exemplo "o sol saiu", é absolutamente compreensível, isto é, nós compreendemos seu significado linguístico, o seu papel possível no enunciado. Entretanto, não é possível ocupar uma posição responsiva em relação a uma posição isolada se não sabemos que o falante disse com essa oração tudo o que quis dizer, que essa oração não é antecedida nem sucedida por outras orações do mesmo falante. Mas neste caso ela já não é uma oração e sim um enunciado plenamente válido, constituído de uma só oração: ele está emoldurado e delimitado pela alternância dos sujeitos do discurso e reflete imediatamente a realidade (situação) extraverbal. (Bakhtin, 2006, p.287).

Como percebemos nessa citação, apareceriam outras vozes, outros textos, outras orações nesse exemplo, que configurariam o enunciado em questão; para Bakhtin, não existe monólogo, toda situação social é por si própria dialógica composta por um auditório responsivo (social).

A atividade de tutoria é basicamente centrada no processo de interatividade, quanto maior o grau de conectividade com o entendimento dos alunos maior será a qualidade do trabalho do tutor.

Tutoria e dialogia devem andar de mãos dadas em prol de um processo de ensino que preze a qualidade da aprendizagem de seus pares. Os problemas de interpretação ou as conhecidas "falhas de comunicação" compreendem-se como os elementos extraverbais que não se apresentaram explicitamente no enunciado dirigido aos interlocutores.

Entendemos que o receptor é na verdade o que Bakhtin (2006) chama de interlocutor; pensamos nos participantes como princípio de auditório social. Tal auditório manifesta suas respostas - atribuições de sentido, diálogo, interação e novas construções enunciativas (produção/renovação de sentido) com referência ao enunciado proposto inicialmente.

Toda compreensão da fala viva, do enunciado vivo é de natureza ativamente responsiva (embora o grau desse ativismo seja bastante diverso); toda compreensão é prenhe de resposta, e nessa ou naquela forma a gera obrigatoriamente: o ouvinte se torna falante. A compreensão passiva do significado do discurso ouvido é apenas um momento abstrato 
da compreensão ativamente responsiva real e plena, que se atualiza na subsequente resposta em voz real e alta. (Bakhtin, 2006, p.271).

É necessário que o tutor compreenda o potencial dialógico, adotando uma atitude enunciativa em suas práticas pedagógicas de formação e atuação, tornando-se ora tutor midiático, ora estudante enunciativo. Assim, entendemos que educação é um processo de enunciação que nasce de uma situação social para o "despertar da consciência", pelo fato de que visa produzir sentidos e conhecimento por meio das interações dialógicas entre os sujeitos. No contexto da tutoria em educação a distância, cabe verificarmos um pouco sobre o sentido e composição das narrativas digitais no que se trata das mídias voltadas às práticas de aprendizagem na educação como enunciados.

O que qualifica a atividade do tutor?

Ser tutor requer formação específica na área de atuação exigida para o curso que está sendo oferecido, demanda também que esse profissional tenha capacidade de comunicação e que goste de trabalhar em equipe. É preciso ter bons conhecimentos de informática, para atuar com as ferramentas na plataforma virtual de aprendizagem.

A ação da tutoria implica estabelecer uma postura de facilitador do processo de aprendizagem, ter responsabilidade, capacidade de argumentação, atender os estudantes em suas dúvidas e realização/compreensão das atividades propostas.

O tutor tem, portanto, uma tríplice função: orientação, docência e avaliação. Todas as atividades e contribuições do estudante devem ser acompanhadas e avaliadas para que o tutor possa interferir no processo de aprendizagem, para que as correções de rumo sejam feitas de imediato e para que o tutor também possa avaliar o grau de satisfação ou de dificuldade do estudante no curso. Para a realização desse trabalho se faz necessário manter anotações regulares do desempenho dos estudantes em fichas ou em outro recurso de controle e fazer a avaliação do desempenho. (Rodrigues, Schmidt, Marinho, 2011, p.97).

Nessa perspectiva, percebemos que é fundamental no trabalho do tutor saber comunicar-se pedagogicamente, visando compreender o novo modo de enunciação viabilizado pela esfera digital. Dessa maneira, acreditamos que esse seja o maior desafio da educação a distância: promover a qualidade por meio do diálogo didático. 


\section{Resultados e Discussão}

Analisamos que discurso pedagógico é aquele que visa contribuir para o aluno apreender os conteúdos curriculares. Quando um tutor escreve um texto, ele está dialogando em outro tempo com outros autores, sobre determinadas temáticas e, ao mesmo tempo nesse processo, deve também pensar o discurso focando um diálogo com seu leitor, no caso os estudantes.

É dessa imensa diversidade de vozes e de suas relações dialógicas que emerge como possível a singularidade que se constituirá explorando o espaço infindo da tensão dialógica das vozes sociais. O sujeito tem, desse modo, a possibilidade de singularizar seu discurso não por meio da atualização das virtualidades de um sistema gramatical (como quer a estilística tradicional), ou da expressão de uma subjetividade pré-social (como querem os idealistas), mas na interação viva com as vozes sociais. Autorar, nessa perspectiva, é orientar-se na atmosfera heteroglóssica; é assumir uma posição estratégica no contexto da circulação e da guerra das vozes sociais; é explorar o potencial da tensão criativa da heteroglossia dialógica; é trabalhar nas fronteiras. (Faraco, 2009, p.87).

No momento em que os estudantes entram em contato com os materiais discursivos do professor, passam também por um processo de pensamento interacional, em que essas vozes se misturam e os signos passam ou não a ter significado.

É importante observar alguns princípios metodológicos (modo de enunciar), que orientam o desenvolvimento da produção das ações comunicativas:

- clareza e o uso adequado da linguagem;

- identificação do perfil dos alunos, aos quais as mensagens serão endereçadas;

- disponibilização e socialização dos estilos próprios de linguagem do tutor e da combinação da escrita entre os participantes do curso.

Apenas disponibilizar textos e solicitar uma leitura não basta, é preciso que o tutor "convide" os alunos e conquiste a atenção deles, mesmo que virtualmente, a fim de que troquem informações e aprendam de maneira conjunta.

O melhor discurso pedagógico a distância é aquele em que a linguagem é clara, coerente, cativante e motivadora de acordo com o público a quem as mensagens serão endereçadas e pelo qual serão visualizadas e interpretadas. 
Um sentido atual não pertence a um (só) sentido, mas tão-somente a dois sentidos que se encontraram e se contactaram. Não pode haver "sentido em si" - ele só existe para outro sentido, isto é, só existe com ele. Não pode haver um sentido único (um). Por isso, não pode haver o primeiro nem o último sentido, ele está sempre situado entre os sentidos, é um elo na cadeia dos sentidos, a única que pode existir realmente em sua totalidade. (Bakhtin, 2006, p.382).

A busca do sentido dialógico do enunciado é o que diferencia a teoria de Bakhtin dos métodos linguísticos, pois de acordo com ele: "o objeto da linguística é apenas o material, apenas o meio da comunicação discursiva, mas não a própria comunicação discursiva, não o enunciado de verdade, nem as relações entre eles (dialógicas), nem as formas de comunicação" (Bakhtin, 2006, p.324). Como vimos anteriormente, o sentido relaciona-se à intenção (ideias) do autor de determinado texto.

A compreensão de uma situação extra verbal, para Bakhtin (2006), constitui-se de três momentos:

A- o horizonte espacial comum dos interlocutores;

B- o conhecimento e a compreensão comuns da situação por parte dos interlocutores; e

C- a avaliação comum dessa situação pelos interlocutores.

Ser tutor e fazer tutoria com qualidade requer bons conhecimentos e uma formação que privilegie teorias de aprendizagem. A docência midiática é um tema que se refere ao ato de ensino e aprendizagem para e com as mídias, em especial das mídias digitais mais utilizadas na educação a distância como as ferramentas do fórum e do chat. Ambas são consideradas tecnologias da informação e da comunicação, a primeira de comunicação assíncrona, o que quer dizer que a ela ocorre, não necessariamente, ao mesmo tempo, a outra de maneira síncrona, ou seja, a comunicação é sincronizada, ocorre em tempo real.

Nesse sentido, planejar estratégias estéticas de aprendizagem é saber escolher os métodos e recursos para as aulas, bem como produzir os enunciados de exercícios, tarefas ou atividades para os estudantes. $O$ enunciado, segundo o senso comum, pelo qual qualquer pessoa saberia dizer do que estamos falando, é a chamada ou o que é para fazer; seria o "comando" ou a "receita" que o professor monta para os estudantes realizarem determinada ação para avaliação do processo de aprendizagem. Entendendo 
assim, poderíamos compreender que a montagem de um enunciado na dimensão da docência do professor midiático é simplesmente uma ação de mediação pedagógica. Pensar o enunciado é tarefa docente, e o desafio do professor midiático é planejá-lo utilizando, para isso, uma ou mais tecnologias (mídias) digitais.

Na tese de Xavier (2002), sobre a constituição do modo de enunciação digital, percebemos que "a digitalização da mídia viabilizada pela Hipermídia ou Multimídia, promotora da confluência de vários meios de comunicação centralizados no computador, proporcionou o acesso a um enorme volume de dados" (p.8). Também é preciso que o tutor adquira a habilidade de estabelecer estratégias pedagógicas para a linguagem em seu modo de enunciação digital que compreende as mídias digitais como tecnologias enunciativas. "Na medida em que o seu compromisso fundamental com o desenvolvimento humano está implicado nos modos como o poder e o saber se exercem, a prática pedagógica - no sentido de orientar a viagem do aprendiz em sua aventura pelo conhecimento -, também é responsável por aquilo que engendra, formula e concebe". (Sobrinho, 2003, p.8).

\section{Considerações Finais}

A proposta aqui abordada foi iniciar um debate sobre os espaços de tutoria como cenário promissor de atividades que primem pela polifonia, e não constituam apenas um ambiente de pensamento unilateral. O pensamento interacional está ligado ao dialogismo de modo a permitir que as interações dialógicas promovam novas maneiras de produzir sentido e também a agregar maior qualidade ao processo de aprender e se expressar dentro dos ambientes digitais.

O tutor tem papel fundamental no processo de inserir uma linguagem que estimule novas práticas incentivadoras da construção do saber em cursos mediados por tecnologias, no âmbito da educação a distância.

Atualmente a perspectiva bakhtiniana contribui de forma revolucionária ao modo de fazer tutoria. Cabe à comunidade acadêmica inserir nele essa nova forma de dialogar com seus aprendizes em prol de uma comunicação com maior qualidade que leve em consideração o conjunto polifônico formado por essas vozes sociais. 


\section{Referências Bibliográficas}

Bakhtin, M. (2006). Estética da criação verbal. São Paulo: Martins Fontes.

Faraco, C. A. (2009). Linguagem \& Diálogo: as ideias linguísticas do círculo de Bakhtin. São Paulo: Parábola.

Moran, J. M. (2013). O que é educação a distância. Acesso em 01 de setembro de 2015, disponível em http://www2.eca.usp.br/moran/wpcontent/uploads/2013/12/dist.pdf

Rodrigues, C. A. F.; Schmidt; L. M.; Marinho, H. B. (2011). Tutoria em Educação a Distância. Acesso em 01 de setembro de 2015, disponível em http://suporte.nutead.org/suporte/wp-content/uploads/2013/02/Tutoria.pdf

Sobrinho, C. A. (2003). Mediação digital e pedagógica. Teias, 4(7-8), 1-13. Disponível em http://www.periodicos.proped.pro.br/index.php/revistateias/article/view/220

Xavier, A. C. S. (2002). O hipertexto na sociedade da informação: a constituição do modo de enunciação digital. Tese de doutorado. Universidade Estadual de Campinas. 